\title{
Another View of the St. Lawrence Project
}

\author{
BY S. WALLACE DEMPSEY \\ House of Representatives, Washington, D. C. Chairman of the Committen on Rivers and Harbors
}

$\mathrm{T}$ HE question as to whether the United States shall help Canada defray the expense of improving $t$ 1e St. Lawrence river, as Mr. Cooper said, is a great question. It is one that involves an enormous amount of money and it would take, the engineers estimate, at least ten years to do the work. So we should know well before we begin what the problem is, what it promises, how it compares with other things. It is a great transportation problem. Primarily at the base of it is the question of transportation. Water power is purely incidental.

I am to talk to you as to how this question presents itself from the standpoint of the United States. Well, we are just at the end of a great war. For the first time in the history of the country we are groaning under the burden of an enormous debt. Every question of Government activity has to be met from that angle and I am going to illustrate it to you. The city of Chicago has furnished a very able man as the first director of the budget, General Dawes,-a man of action, a man of brains. When he provided in the first budget that was ever presented to a Congress of the United States for the expenditure for all our rivers and harbors, how much do you think he estimated? We have been talking about one half a billion or $500,000,000$ dollars as the cost of the development in the international section of the St. Lawrence. And on the 50 per cent basis, one half of that would be $250,000,000$ dollars. But it is not the 50 per cent basis at all, that is proposed by the Joint Commission organized by Canada and the United States to study and report on the St. Lawrence route and what we are considering today is what the Joint Commission recommends. They have been asked to investigate and to report upon this subject and we are proposing to act on their report. They do not propose that the United States shall bear one half of the expense of this great undertaking. They say that the disproportion in wealth, in population, in commerce, between the United States and Canada shall disappear, that we shall bear-the two countries shall bear,-that expense in proportion to population, wealth and commerce, and that means, as you all know, that the United States shall bear nine-tenths of the cost. And we don't stop there. A great canal has already been dug, the Welland Canal. It is practically completed. Its expense has been borne by the Dominion of Canada and this Joint Commission proposes that the United States shall share in the same proportion the cost of that canal.

We have done the work of improving the Great Lakes. We have dug the canals, we have improved the harbors, we have done all the work that leads to their enormous commerce, the cheapest commerce in

Address delivered at the Spring Convention of the A.I.E.E., Chicago, Ill., A pril 21, 1922. the world that floats down from Duluth all the way to Buffalo. And if we should pay nine-tenths of the cost of this canal, which Canada has already constructed, why shouldn't Canada come over and bear its proportion of the cost of this work which we have done for many, many years and which we are still doing?

When as I say, General Dawes began to consider what he would allow to the United States for all of its rivers and harbors in this great country of ours, with about five thousand miles of sea and gulf coast, with 25,000 miles of navigable rivers, with 25,000 more that can be made navigable, how much money, as again $s t$ nine-tenths of somewhere from $500,000,000$ to a billion and a half, which is proposed for this one route, how much do you suppose the General expected to allow us for all of this commerce within our country? Thirteen millions of dollars. And that is all he thought that the present conditions of this country could allow, with its burden of taxation, with the people paying high prices, as Mr. Cooper says, for labor and for supplies, and for materials.

The Committee on Rivers and Harbors convinced him that he was wrong, convinced General Lord, the Finance Officer of the War Department, convinced Secretary Weeks that he was wrong, and as a result they consented to $27,000,000$ dollars. At that time we expected 15,000,000 dollars could be used from unexpended balances to the credit of River and Harbor projects, and it turned out that there weren't unexpended balances available. So we went on the floor of the House and we had to make a fight and a strenuous fight, and a fight for which we had to prepare for four or five weeks, in order to enable us to get an additional 15,000,000 dollars for our rivers and harbors.

What was the condition of our rivers and harbors? Why did we need this money? We needed it for two reasons. First, during the war not a dollar's worth of work was done upon any river or harbor in the United States, for the Secretary of War must have certified that it was necessary to win the war. Since it could not come within that definition the harbors were allowed to silt and fill up. And let me give you an illustration. Down in Mobile we adopted a project for deepening the harbor thirty feet, many years ago, and today the harbor in Mobile has less draft than it had when we adopted the project and what is true of Mobile is true generally of the rivers and harbors in the United States, they have been going backward instead of forward ever since the war broke out.

In addition to that this country is growing very rapidly and we need to use all of our transportation facilities, and keep furnishing and supplying new ones from time to time to meet the constantly increasing and multiplying demands of commerce. And on that 
account it is necessary that we should have our rivers and harbors used to their maximum.

One other thing. Owing to the way that the railroads were managed during Government control, owing to the fact that their operation became enormously more expensive, owing to the fact that freight rates in consequence have soared to an unheard of level, the only relief in sight was by cheap transportation by water, and how could we have it unless we improved our waterways? And then we had living examples of the fact that it was important to improve our waterways. All we had to do was to look to the south of us and we found on the Mississippi River that under Government management, which is always wasteful, always inefficient, we found that in spite of that Government boats are being operated there under Government control, and with all of the wastefulness, with all of the extravagance, with all of the inefficiency of Government operation those boats are paying, taking into account every kind of an overhead charge which it is possible to put into the account against them.

How has it come about that this traffic upon the Mississippi, for the first time in the history of the stream, is really profitable? In a very natural way. In the olden days they used to fit out a barge on the Ohio River and they would send it down the Ohio and down the Mississippi and when it reached New Orleans they would break it up and sell it for firewood. Why? Because they couldn't get a return cargo and it cost more to take it back up the river unloaded than it would cost to build a new raft up on the Ohio. And for the first time in the history of the Mississippi they have found that they can get return cargoes to the full capacity of all the boats, and that is what has made the navigation of the Mississippi profitable, in spite of the drawbacks to which I have referred.

That is only one example of the use to which we can put our waterways and of the necessity of using them. So here we are, from the Governmental standpoint in this position, of needing great sums of money to improve our own waterways in a time when we owe a huge debt and must economize, and we want to examine the whole thing carefully and fairly. We are all Americans, we all have the interests of the whole country at heart. If it is the best thing to build this waterway we want to build it, but we don't want to decide it as a matter of sentiment, we don't care to decide it as a matter of feeling, we want to examine it soberly as we would examine any other business question in the light of the facts, and see whether it will bear such an examination.

We find that it is well nigh impossible to get what our own waterways need as a sheer and dire necessity, we find as we look back over the history of the past twenty years that we have only had about $30,000,000$ dollars a year for all our waterways. We find that last year we spent $40,000,000$ dollars. We find that it is going to be necessary to spend $100,000,000$ of dollars a year on the waterways in the United States to develop and maintain them. And yet as I say, those in charge start off by offering us $13,000,000$ dollars to meet a necessity that requires $100,000,000$ dollars.

In the face of facts like these, should we not examine a proposal to spend hundreds of millions of dollars on one waterway traversing a foreign country? Isn't that fair, that we should examine it closely, that we should scan it, that we should be entirely satisfied before we reach a conclusion?

Let us take the report of the Joint Engineers, first of all, and see, because that is what we have before us, what they propose. They say that we are to have a channel of 25 feet through the St. Lawrence, and then say we are to be satisfied with the channels in the Great Lakes, except that in the pivotal harbors and through some of the channels we may get an increased depth from 20 to 21,22 or 25 feet, which are the controlling depths today. What is the situation as to that depth? Is that depth sufficient for the purpose for which it is intended? Is it going to enable ocean going vessels to traverse the St. Lawrence route,ocean going vessels of a size that can compete with the lake freighters that now carry the traffic of the lakes? We have on the Great Lakes today freighters carrying 14,000 tons, and everyone knows that is the cheapest transportaion anywhere in the world. These great freighters are practically square boxes which require scarcely any space for coal, they are loaded and unloaded in an incredibly short space of time and owing to the fact that they don't need the reserve space, that loading and unloading is so very cheap, that the cost of construction is very low, transportation on the Lakes is, for its cheapness the marvel of the world.

I don't know myself the comparative average costs of transportation on the Great Lakes and of that on the ocean. I recently had the pleasure of having a joint debate with Senator Ransdell of Louisiana, an ardent advocate of the St. Lawrence route, at Boston, when Mr. Harriman, who is to follow me, was present and in that debate Senator Ransdell made the statement that the average cost of transportation per ton per mile on the ocean was three mills, and that the average cost on the Great Lakes was one mill. Now I know nothing about the accuracy of his figures, but I am reliably advised that the cost of transportation on the ocean is much greater than the cost on the Great Lakes. So starting with that as a basis, I ask how you can, for the purpose of economy, substitute ocean navigation, which is far more expensive than navigation on the Great Lakes, for shipment by lake freighters and yet cheapen the cost of transportation to the wheat grower of the northwest? You start with that as your primary proposition and then you come to examine the details, and see whether it is simply the average cost of transportation on the Great Lakes and of transportation on the ocean, that you have to meet, or whether there are other factors that enter into the problem and make it 
more clear still that you cannot compete by an ocean going boat with the cost of transportation which is established today by the lake freighter. What kind of ocean going boats, what capacity of ocean going boats will be able to traverse the Great Lakes? That is your first problem. Here you have a depth, a controlling depth of 20 to 22 feet, because your boat must be able to traverse the very shallowest section. The steamship companies say that the largest sized boat, that could traverse the Great Lakes and its channels and harbors, would be one of 4000 tons capacity, and they would have to compete on the Great Lakes with these freighters carrying 14,000 tons. What would the result be? You wouldn't have the ordinary competition between the cost on the ocean and the cost on the Lakes, but you would have in addition to that, not a competition between two boats, one an ocean boat carrying 14,000 tons and another a lake freighter of the same carrying capacity, but you would have this small, insignificant ocean boat, which isn't large enough to be economical on the ocean competing with a 14,000 ton lake freighter, 4000 tons is all that could be carried in an ocean ship upon the St. Lawrence route. Can there be any doubt that the 14,000 ton Lake freighter would carry freight very much more cheaply than the 4000 ton ocean ship?

Before I leave that question of depth, let us go to another demonstration of the fact that the proposed depth would be insufficient. The Joint Commission in its report says that the controlling depth from Montreal to the sea, a distance of a thousand miles, is 30 feet, but they say that that is being improved to 35 feet. What does that mean? It means that Canada and Great Britain have used that channel for ocean going vessels for a very long time and as the result of all of that experience they have found that 30 feet even isn't a sufficient depth, and that to navigate the channel economically, to get the best results, the lowest freight rates, and to make it profitable to use the channel, you must have a depth of 35 feet.

So here is the channel from Montreal to the sea, one thousand miles long and it is proposed to supplement that by a channel, from Montreal west, of twenty to twenty-two feet, and join together that mismatched, dissimilar pair and call it a joint and complete route. Of course it is utterly impossible.

What next do you find? That there isn't simply the disproportion of costs between the lake freighters and the ordinary ocean going boat, but that there is a great difference because they are built on an entirely different principle. The one is built much higher than the other, the ocean vessel having to be built for the buffetings of that enormous expanse of water. But you don't have to build simply the ordinary ocean going boat for the St. Lawrence route. The Encyclopedia Brittanica in its latest edition says that for the navigation of the St. Lawrence route you must have an especially strongly constructed vessel because of the fact that icebergs are present in that channel at all times of the year.

That adds to the overhead, and to the cost of construction; the interest charges, as Mr. Cooper pointed out, go on, and as a result, the cost of carrying the wheat, if you are going to carry it in that ocean-going vessel, is increased by the interest on that added cost of construction.

Then the Joint Commission says that it is not simply a question of fogs, tides, nor icebergs, but the combination of all of these difficulties and dangers of that route, there resulted in 1909 the adoption of what was known as the British North American Clause of Marine insurance requiring a very high marine risk rate all through the St. Lawrence. The Joint Commission in this report recommending this route says that that is a handicap to the usefulness of the route.

Those are a few of the objections to this route. Mr. Redfield, Secretary of Commerce, investigated this matter in 1918 and made a report in which he said that there never would come a time when ocean-going vessels would carry freight in the restricted channels of a canal or a river or upon the Lakes, that the over-head makes it absolutely impossible, the cost of construction, the cost of maintenance, the cost of operation was so very much greater for all boats of that description.

A report was made by the Army Engineers at about the same time, and they reached the same conclusion. I don't understand that any Board of Army Engineers has united in this report of the Joint Commission. My understanding is that a single Colonel from the United States Army was designated on our part, and an Engineer on the British side was designated, and those two engineers joined in the making of this report.

Let us take this St. Lawrence route and examine it regarding waterpower. It runs along the American border for a very short distance. In that distance there occurs one of the opportunities to create water power. Every one in the United States is in favor of the development of the water power on the St. Lawrence, on the Niagara, at every point in the United States where it can be developed. It is the one thing since I have been in Congress that has been my especial care, for which I have fought incessantly, day in and day out, ever since I have been a member of that body, because in the district, which I have the honor to represent, there is located the greatest water power in the world, the power of Niagara. We have developed a small part only of the great power there and I have seen a little village of 3000 people grow to a city of 60,000 people, (with $\$ 200,000,000$ of assessed valuation), which is the greatest electrochemical center in the world, I saw there the development of more of the things that went to the successful prosecution of the war than were made at any other point in this great and rich nation of ours, with all of its broad territory. So, of course, I believe in the development of power, everywhere throughout our country. But the develop- 
ment of power anywhere, if the power is worth developing, doesn't have to be done at Government expense. Go down and examine the applications for the development of water power in the Federal Power Commission at Washington. Talk with the Secretary, Mr. Merril, find if there is any water power that is worth having for which there isn't an application pending. Find if there aren't competitors in each case where the power is worth anything. Find if men aren't eager, not ready, but eager and ready to advance the money at a moment's notice, the instant they can get the license. That is the situation as to the development of power.

Then if anyone says to you, "Why, you can do better by Government development than you can by private development," say to him, that he can look back to the period when the Government controlled the railroads and it had them for only 26 months under operation and say to him that during that period the Government lost the stupendous sum of one billion dollars, one twentysixth of its total national debt today incurred by reason of the war. And say to him that you had the poorest service during Government operation you ever had in the history of your country and if he wants a practical illustration, tell him that you couldn't trace a freight car from the time it left a yard until it reached its destination, if it ever reached it. And then tell him, if he wants a particular instance of how bad it was, to go down into New England and find their roads practically ruined and if he will examine the records he will find that during the first 18 months of Government control they earned only 15 per cent of the standard return,- of the average of their earnings for the three years preceding Government control,- and, then if he says to you, "Why, railroads are not water power, and we are talking about water power," tell him to go down to Niagara and visit both sides of the river there and then go on to Quebec and tell him he will find that on the Niagara, on the American side we furnish power 40 per cent cheaper to the consumer than they do over on the Canadian side where it is government controlled, and then tell him to step down to Quebec where it is developed by private enterprise and he will find that it is produced there 32 per cent cheaper under private enterprise than it is by the Government.

So far as the Government part of this is concerned the Government doesn't need to, and shouldn't, take any hand in the development of the power, and there isn't a man in the United States who recognizes more fully than I do, the importance of power development or who is more earnestly, in season and out of season, every day of the year, for water power development.

Let me say one word more about this question of water power. Many people say to you that water power will pay the entire cost of the improvement of the St. Lawrence. Well I say to you that as a matter of law, it can't do that and as a matter of justice and fairness it shouldn't do that. This water power will be developed under the General Water Power Bill and I had the honor personally to make the fight which kept boundary streams in the General Water Power Bill. You have the legislation ready and all you have to do is to give private capital the opportunity to develop the power.

The General Water Power Bill provides this,--and it is not going to be changed because it is a just and fair bill,--it provides that when the state where the water power is developed has a Public Service Commission, that that Public Service Commission shall regulate the charges. On what principles are they regulated? They regulate them on this basis,--they allow the companies to prove what it costs per horse power to develop the power which they are selling. They allow them a reasonable sum for depreciation and amortization and then they allow them a reasonable profit. Now how are they going to allow for something that hasn't anything to do with water power? Because navigation has no connection with water power, navigation is an entirely separate and distinct thing. How can they allow those who develop the water power to charge the consumers of the power for the development of navigation in the St. Lawrence? It can't and shouldn't be done and we shouldn't, for one moment, delude ourselves with any dream that we are going to pay the entire cost of improvement of navigation out of the development of the water power. Why, this country needs the improvement of its transportation facilities. All along the Atlantic Coast, starting in from Boston and Portland, including every southern port, Baltimore, Savannah, Charlestown, Mobile, Galveston, New Orleans, every port is growing from day to day and year to year in its commerce, and most of these ports are growing rapidly in the export of wheat.

Do you realize, - and it seems impossible for those who haven't examined it to realize it,--do you realize that on the Houston Ship Canal they are carrying $10,000,000$ tons of freight a year? Of what kind? They are carrying that material which is just as useful as water power,-oil. And it is increasing in quantity from month to month and they have found down there that it is not economical to have a 25 foot water-way, on that little stream leading up from the ocean, only about 50 or 60 miles long. They have found that 20 to $22 \mathrm{ft}$. depth wouldn't do. They have 25 feet and they are before Congress at this session to get it increased to 30 feet and the Committee, of which I have the honor to be Chairman, has reported a bill to give them their 30 feet depth. There isn't anything any more important to the development and the progress of this nation than the use of oil and its various products. There isn't anything that is multiplying in its use from day to day, with anything like the rapidity of oil, and there is no place where it is being shipped as it is down in those gulf ports. And there is one of the things that you have to do. We haven't any money in this Bill for deepening these harbors. We are simply going to 
adopt the project and then trust to Providence that we can persuade Congress that it is necessary to let this oil come to us just as cheaply as it can, let the cost of gasoline go down five cents, if it is possible to do so take it out of the transportation costs. Isn't that a real problem to be weighed against the St. Lawrence route? Isn't it as important to us as developing a waterway in the foreign country? And that is only one of our pressing needs. Here is the Ohio River. Congress over 26 years ago adopted the project of improving the Ohio River by locks and dams. In 1910, after seven of the 54 locks and dams were completed, we provided that we should complete that improvement within 12 years. Twenty-six years have passed. We have improved 500 miles of it, about half, and the rest remains to be done.

The Ohio runs between coal mines and forests, rich fields waving with grain and all the products of the soil and, in its upper portion, through a beehive of manufacturing plants which have caused that section to be called "The Workshop of the World;" and cheap transportation can be had to carry all these products from Pittsburg, Cincinnati, St. Paul, St. Louis, New Orleans and intermediate points; and all of those great American cities which we love just as much as we do Montreal and Toronto, which are just as near our hearts; yet how are we going to get the money to complete this great transportation project if we spend hundreds of millions of dollars upon one foreign waterway, when it is hard to wring thirty millions of dollars out of an unwilling Congress for all the waterways of this great country of ours.

And then the Mississippi flows down dividing our whole empire of states, with great grain fields on both sides of it, furnishing to the vast territory tributary to it a far shorter route to the sea than the St. Lawrence route, and the southwest pass needs to be improved, and it will take millions to complete the work. Where are we to find the money if we spend all our income on the St. Lawrence? We never have provided that the nation should deepen the harbors on the Mississippi and they are all filled and silted and haven't the requisite depth. Don't we need the money to do that? Shouldn't we provide it? Don't we love all those cities down there just as much as we do Canada? And isn't it just as important to the life and the prosperity of this nation as a whole, that that great river be improved?

And so you could go over the various waterways of the United States, taking them one by one, pointing to their use in the national system of transportation. Why, as I think of this St. Lawrence route, I think of something that is in the mind of this nation because the President has recently brought it to the attention of
Congress. I think of the fact that during the war, at an enormous expense, at the expense of billions we built up a great Merchant Marine only to find that the effort to operate it lost us a million dollars a day for the 365 days of the year. And finally we threw up our hands in despair and said that we couldn't stand the losses and that we had demonstrated that the Government couldn't operate ships, and the President came to Congress and said that we must sell these merchantships, these hundreds of thousands of tons that we had built at this enormous expense, let them pass into private hands, but under the American flag. But he said it was demonstrated with equal clearness that owing to our high cost of labor it was impossible for private parties even with efficiency, with energy, with capacity, with all that goes to make business successful, it would be impossible for them to operate those ships successfully in competition with the cheaper paid labor of Europe and with the experienced seamanship of those countries, and so he proposed that we should subsidize the American Merchant Marine, pay them 30 to 50 millions of dollars a year in order to enable them to operate upon the ocean, as Congress is going to do it, in my judgment.

If it is impossible for an American Merchant Marine to operate upon the free ocean, the Atlantic and the Pacific, with all the advantages they offer, how I ask you, when you can only bring up the St. Lawrence a boat with 4000 tons capacity, which is uneconomical even on the ocean itself where they require at least 7500 to 10,000 tons to be economical, how are you going to induce private enterprise to enter upon any such business venture as navigating ocean ships of that capacity on the St. Lawrence route? Deepen and widen the St. Lawrence, spend your hundreds of millions of dollars, starve your own waterways in the United States, do this for a third of the life of one generation, ten years, and when you have the waterway there ready, to the depth and of the draft that the Joint Commission recommends, what are you going to do with it when you can't operate ships upon the ocean of proper tonnage to be economical, when you can't operate them without a subsidy, how are you going to get any one to operate them upon the St. Lawrence route?

And are you going to come then and ask for a subsidy for this route for a thousand miles up to Montreal from the ocean and then on to Duluth? And do you think that the nation is in condition to grant the subsidy or that they will believe-in the enterprise when they have examined it sufficiently to subsidize the boats that would navigate the channel? I am thoroughly convinced that this is a vision. 